ZOOLOGIA 32 (1): 1-8, February 2015

http://dx.doi.org/10.1590/S1984-46702015000100001

\title{
Missing for the last twenty years: the case of the southernmost populations of the Tropical Mockingbird Mimus gilvus (Passeriformes: Mimidae)
}

\author{
Mariana S. Zanon ${ }^{1,2}$, Mariana M. Vale ${ }^{3} \&$ Maria Alice S. Alves ${ }^{2,4}$ \\ ${ }^{1}$ Programa de Pós-graduação em Ecologia e Evolução, Instituto de Biologia Roberto Alcantara Gomes, Universidade do \\ Estado do Rio de Janeiro. Rua São Francisco Xavier 524, 20550-011 Rio de Janeiro, RJ, Brazil. \\ ${ }^{2}$ Departamento de Ecologia, Instituto de Biologia Roberto Alcantara Gomes, Universidade do Estado do Rio de Janeiro. \\ Rua São Francisco Xavier 524, 20550-011 Rio de Janeiro, RJ, Brazil. \\ ${ }^{3}$ Departamento de Ecologia, Instituto de Biologia, Centro de Ciências da Saúde, Universidade Federal do Rio de Janeiro. \\ Avenida Carlos Chagas 373, Ilha do Fundão, Cidade Universitária, 21941-902 Rio de Janeiro, RJ, Brazil. \\ ${ }^{4}$ Corresponding author. E-mail: masaal@globo.com
}

\begin{abstract}
The Tropical Mockingbird Mimus gilvus (Vieillot, 1808) is a widespread species in the Neotropics, but its southernmost populations in Brazil are ecologically (and possibly taxonomically) distinct, occurring only along the coast in restinga vegetation. Once considered the most common bird in restinga, it is becoming increasingly rare, likely due to habitat loss and illegal capture of nestlings. We conducted field surveys to provide an up-to-date distribution of the Tropical Mockingbird in the southernmost portion of the species' range, in the state of Rio de Janeiro, supplying an estimate of its current regional population size and conservation status. We surveyed 21 restinga remnants in Rio de Janeiro, covering all major restinga areas in the state. For sites where the species' presence was confirmed through transect line surveys, we estimated the local population size. The species was found at only four sites. The mean local population density was 52 individuals per $\mathrm{km}^{-2}$. The estimated current and historical Extent of Occurrence (EOO) were $256 \mathrm{~km}^{2}$ and $653 \mathrm{~km}^{2}$, respectively. Combining the population size and EOO results, we estimated that the population of the state of Rio de Janeiro currently ranges from 2,662 to 13,312 individuals, corresponding to an estimated reduction of $61 \%$ to $92 \%$ in population size in the last 20 years. The species, therefore, can be considered "Endangered" in the state of Rio de Janeiro. We recommend that a taxonomic study of the southernmost populations is carried out in order to clarify whether they represent a different, likely threatened species. We also recommend that the environmental regulations that protect restingas are used towards the protection of these populations.
\end{abstract}

KEY WORDS. Brazil; conservation status; IUCN; restinga; Rio de Janeiro.

The Tropical Mockingbird, Mimus gilvus (Vieillot, 1808), is widespread in the Neotropics, but some of its populations at the southernmost edge of its distribution are disappearing. The Tropical Mockingbird ranges from Mexico to Brazil, reaching its southernmost limit in the Brazilian state of Rio de Janeiro (Meyer de Schauensee 1970, Ridgely \& Tudor 1989, Sibley \& MonROE 1990, Sick 2001, Cody 2005), where it is considered threatened (Alves et al. 2000). There are also records of vagrant individuals found further south, in the Brazilian states of Paraná (SCHERER-Neto et al. 2011, Bornschein et al. 1997) and Santa Catarina (Ghizoni-Jr \& Azevedo, 2010). The species is absent from the checklist of birds of the state of São Paulo (Silveira \& Uezu 2011), although Bornschein et al. (1997) mentioned a supposed record of the species there. In spite of occupying most of the South American continent, in the eastern coast of Brazil the Tropical Mockingbird only occurs in restinga (SІск 2001), an ecosystem of the Atlantic Forest biome that is located between the forest and the sea, and is mainly composed of sandy coastal plains (Araujo 1992).

There are several described subspecies of Mimus gilvus (Hellmayr 1934, Pinto 1944, Cody 2005, Restall et al. 2007), including M. gilvus antelius Oberholser, 1819, which occupies the coast of Brazil from the state of Pará in the North, to Rio de Janeiro in the South. Mimus gilvus antelius is considered to be endemic to the Atlantic Forest (Gonzaga et al. 2000), and in the state of Rio de Janeiro it is only found in restinga (ReIs \& GonZAGA 2000). There are reasons to believe that M. gilvus antelius is a distinct species (CoDy 2005).

According to PARKer et al. (1996), the Tropical Mockingbird is not very sensitive to habitat disturbances, and it is a priority neither for research nor for conservation. In southeastern Brazil, however, the species is highly susceptible to

2015 | Sociedade Brasileira de Zoologia | www.sbzoologia.org.br | www.scielo.br/zool All content of the journal, except where identified, is licensed under a Creative Commons attribution-type BY-NC. 
extinction. It was once considered the most common bird in restinga (Sіск 2001), but in the last decades, it has disappeared from a large number of restinga remnants in the state of Rio de Janeiro (Teixeira \& Nacinovic 1992, Araujo \& Maciel 1998, ArgelDe-Oliveira \& Pacheco 1998, Gonzaga et al. 2000). Mockingbirds are well-known for their ability to sing, and for this reason human pressure acts on them not only through habitat loss and degradation, but also through illegal trade (ARGEL-DEOliveira \& Pacheco 1998, Alves et al. 2000).

Currently, the Tropical Mockingbird is listed as "Endangered" in the red list of Rio de Janeiro and Espírito Santo, which, together with Pará, are the only Brazilian states that have such lists within the species' range (Alves et al. 2000, SimON et al. 2007, PARÁ 2007). Furthermore, the subspecies M. gilvus antelius is listed as "Almost Threatened" in Brazil (Machado et al. 2005). However, none of these lists were based on quantitative data, and only SIMON et al. (2007) provided a justification for the listing, based on an estimated Extent of Occurrence $<5,000 \mathrm{~km}^{2}$.

We conducted field surveys of the Tropical Mockingbird to provide up-to-date occurrence records in the southernmost portion of its range, in the state of Rio de Janeiro, and to supply an estimate of the current size of its population in the state. We then used this information to reassess the species' conservation status at the state level, based on two IUCN criteria: Extent of Occurrence and Population Size (IUCN 2001).

\section{MATERIAL AND METHODS}

This study was conducted in the state of Rio de Janeiro, Brazil, which represents the southernmost portion of the geographic range of the Tropical Mockingbird. We surveyed 20 areas with restinga remnants within the known geographic range of the Tropical Mockingbird, using line transects and/or casual survey, in order to establish the current distribution of the Tropical Mockingbird in the state (Table I). Both methods were used to confirm the occurrence of the species in each of the visited remnants. The areas were selected based on: I) previously known records of the species, II) restinga remnants indicated by RocHA et al. (2007), and III) availability of the species' habitat, i.e., restinga with open shrubby vegetation reaching the shoreline (SICK 2001). To locate these remnants, we used Google Earth satellite imagery. One additional area was surveyed (area 21 in Table I), outside the species' known range, to investigate a dubious record (ARgel-De-Oliveira \& Pacheco 1998) to the south of its known distribution. Surveys were conducted from August 2008 to November 2009, always under stable weather. The same researcher (MSZ) performed all surveys to standardize detectability.

In 15 of the 21 restinga remnants, line transects were applied systematically (Table I). In each of these remnants, one or more line transects were performed, totaling 18 . The only restingas where we established more than one line transect were Marambaia (two transects) and Massambaba (three), which are among the largest restinga remnants in Rio de Janeiro. Transects were $2 \mathrm{~km}$ long, positioned at the shoreline near the border between the restinga and the beach. These boundaries are at natural sandy mounds, known as the beach ridge ("cordão arenoso" in Portuguese), which represent the highest point of restinga. Mimus gilvus individuals are very conspicuous. They frequently vocalize during the day, and always choose exposed portions of the highest perches to do it (V.C. Tomaz, pers. comm.). For these reasons, they are very easy to spot, even from the beach line. The surveys were always performed in the morning, beginning around six hours. They lasted, on average, 1h30min, with a little variation among the areas due to differences in topography and number of individuals recorded. Binoculars ( 10 x 50, Olympus or Nikon) were used to search for the birds. Observations were made from the line transect to the interior of the restinga, excluding bare sandy beach. Both visual and auditory contacts were considered. The survey effort was complemented with seven casual expeditions (Table I). These expeditions were also based on the line transects and occurred after the systematic survey, between 7:00 a.m. and 3:00 p.m., in "minor" restinga remnants next to our main study areas. The only methodological difference is that these expeditions were not made during periods of greater birds activity, i.e., the beginning of the morning, although M. gilvus is a very active bird all day long (V.C. Tomaz, pers. comm.). Sites were considered to belong to "minor" restinga remnants when they: 1) had damaged and/or very reduced areas of restinga vegetation, 2) did not have open shrubby vegetation or, if open shrubby vegetation was present, it did not reach the shoreline, and 3) there were no previous records of the Tropical Mockingbird (excepting Enseada do Bananal) in these areas. At all these sites, transects of at least $2 \mathrm{~km}$ at the shoreline or on main trails in the natural vegetation were used to search for tropical mockingbirds. In areas where the presence of the Tropical Mockingbird was confirmed through transect line survey, a point count (Hutro et al. 1986, Matros et al. 2009) was used to estimate local population size. Ten points were positioned linearly, at $200 \mathrm{~m}$ intervals, parallel to the transect line, but $100 \mathrm{~m}$ further inside the vegetation than the transect line. The surveys, which began at 6:00 a.m., and lasted 10 minutes on each point, recorded all visual or auditory contacts with tropical mockingbirds into a $100 \mathrm{~m}$-radius circle from the point. Contacts that occurred when the researcher was between two consecutive point counts were not recorded. Point counts were performed just once in each site. The point count surveys ran from October 2008 to August 2009, always when the weather was good (i.e., without rain).

Local population size was used to calculate population density (D) for each area, individually, where the point count method was applied. Population density was defined as the number of individuals counted divided by the area of the site surveyed. We employed the formula $D=\Sigma \pi r^{2}$, where $N$ is the sum of individuals registered at all 10 point counts and $\Sigma \pi r^{2}$ is the sum of the ten $100 \mathrm{~m}$-radius circles areas $\left(\Sigma \pi \mathrm{r}^{2}=0,314 \mathrm{~km}^{2}\right)$. 
Table I. Areas surveyed for the Tropical Mockingbird in the state of Rio de Janeiro, Brazil. Surveyed Areas: numbers correspond to areas depicted in Figs. 1-3, and letters in parenthesis to the source of previous record for the species in the area (areas with no source were selected from RochA et al. (2007) and/or satellite imagery). Geographic Coordinates: refer to the midpoint for the area. Survey Methods: (LT) Line Transect, (CS) Casual Survey, (PC) Point Count.

\begin{tabular}{|c|c|c|c|c|c|}
\hline Surveyed Areas & Geographic coordinates & Size (ha)* & Municipality & Species Present & Survey Method \\
\hline 1. Barra de Itabapoana & $21^{\circ} 20^{\prime} 33^{\prime \prime} \mathrm{S} / 40^{\circ} 57^{\prime} 48^{\prime \prime} \mathrm{W}$ & 569 & São Francisco do Itabapoana & No & LT \\
\hline 2. Grussaí (a) & $21^{\circ} 45^{\prime} 20^{\prime \prime} \mathrm{S} / 41^{\circ} 01^{\prime} 22^{\prime \prime} \mathrm{W}$ & 302 & São João da Barra & No & LT \\
\hline 3. Jurubatiba (a) & $22^{\circ} 16^{\prime} 43^{\prime \prime} \mathrm{S} / 41^{\circ} 38^{\prime} 58^{\prime \prime} \mathrm{W}$ & 25,141 & Carapebus & Yes & $\mathrm{LT}, \mathrm{PC}$ \\
\hline 4. Itapebussus (a) & $22^{\circ} 29^{\prime} 39^{\prime \prime} \mathrm{S} / 41^{\circ} 53^{\prime} 58^{\prime \prime} \mathrm{W}$ & 750 & Rio das Ostras & Yes & $L T, P C$ \\
\hline 5. Peró $(a, b)$ & $22^{\circ} 51^{\prime} 28^{\prime \prime} \mathrm{S} / 41^{\circ} 59^{\prime} 13^{\prime \prime} \mathrm{W}$ & 427 & Cabo Frio & No & LT \\
\hline 6. Foguete/Dunas (a) & $22^{\circ} 54^{\prime} 49^{\prime \prime} \mathrm{S} / 42^{\circ} 02^{\prime} 09^{\prime \prime} \mathrm{W}$ & $N / A$ & Cabo Frio & No & LT \\
\hline 7. Massambaba $(\mathrm{a}, \mathrm{d})$ & $22^{\circ} 56^{\prime} 38^{\prime \prime} \mathrm{S} / 42^{\circ} 10^{\prime} 58^{\prime \prime} \mathrm{W}$ & 7,360 & Araruama & Yes & $\mathrm{LT}, \mathrm{PC}, \mathrm{CS}$ \\
\hline 8. Jacarepiá (a) & $22^{\circ} 56^{\prime} 04^{\prime \prime} \mathrm{S} / 42^{\circ} 26^{\prime} 45^{\prime \prime} \mathrm{W}$ & 508 & Saquarema & No & LT \\
\hline 9. Jaconé (a) & $22^{\circ} 56^{\prime} 15^{\prime \prime} \mathrm{S} / 42^{\circ} 38^{\prime} 47^{\prime \prime} \mathrm{W}$ & 40 & Maricá & No & CS \\
\hline 10. Ponta Negra ${ }^{(a)}$ & $22^{\circ} 57^{\prime} 29^{\prime \prime} \mathrm{S} / 42^{\circ} 41^{\prime} 42^{\prime \prime} \mathrm{W}$ & 126 & Maricá & No & CS \\
\hline 11. Barra de Maricá (a) & $22^{\circ} 57^{\prime} 43^{\prime \prime} \mathrm{S} / 42^{\circ} 50^{\prime} 41^{\prime \prime} \mathrm{W}$ & 272 & Maricá & No & LT \\
\hline 12. Itaipuaçu (a) & $22^{\circ} 58^{\prime} 09^{\prime \prime} \mathrm{S} / 43^{\circ} 00^{\prime} 04^{\prime \prime} \mathrm{W}$ & 1,020 & Maricá & No & LT \\
\hline 13. Itacoatiara/Banana ${ }^{(a, c)}$ ) & $22^{\circ} 58^{\prime} 28^{\prime \prime} \mathrm{S} / 43^{\circ} 02^{\prime} 00^{\prime \prime} \mathrm{W}$ & N/A & Maricá & No & CS \\
\hline 14. Itaipu (a) & $22^{\circ} 58^{\prime} 20^{\prime \prime} \mathrm{S} / 43^{\circ} 02^{\prime} 44^{\prime \prime} \mathrm{W}$ & 23 & Maricá & No & LT \\
\hline 15. Marapendi & $23^{\circ} 00^{\prime} 46^{\prime \prime} \mathrm{S} / 43^{\circ} 23^{\prime} 54^{\prime \prime} \mathrm{W}$ & 621 & Rio de Janeiro & No & CS \\
\hline 16. Recreio dos Bandeirantes & $23^{\circ} 01^{\prime} 47^{\prime \prime} \mathrm{S} / 43^{\circ} 28^{\prime} 05^{\prime \prime} \mathrm{W}$ & $\mathrm{N} / \mathrm{A}$ & Rio de Janeiro & No & LT \\
\hline 17. Chico Mendes & $23^{\circ} 01^{\prime} 27^{\prime \prime} \mathrm{S} / 43^{\circ} 28^{\prime} 18^{\prime \prime} \mathrm{W}$ & 57.3 & Rio de Janeiro & No & CS \\
\hline 18.Prainha & $23^{\circ} 02^{\prime} 27^{\prime \prime} \mathrm{S} / 43^{\circ} 30^{\prime} 20^{\prime \prime} \mathrm{W}$ & 1 & Rio de Janeiro & No & CS \\
\hline 19. Grumari & $23^{\circ} 02^{\prime} 53^{\prime \prime} \mathrm{S} / 43^{\circ} 31^{\prime} 28^{\prime \prime} \mathrm{W}$ & 158 & Rio de Janeiro & No & LT \\
\hline 20. Marambaia (a) & $23^{\circ} 04^{\prime} 37^{\prime \prime} \mathrm{S} / 43^{\circ} 53^{\prime} 50^{\prime \prime} \mathrm{W}$ & 4,940 & Rio de Janeiro & Yes & LT, PC \\
\hline 21. Praia do Sul (a)** & $23^{\circ} 10^{\prime} 41^{\prime \prime} \mathrm{S} / 44^{\circ} 16^{\prime} 31^{\prime \prime} \mathrm{W}$ & 397 & Angra dos Reis & No & LT \\
\hline
\end{tabular}

We calculated both the historical and current extent of occurrence of the Tropical Mockingbird in the state of Rio de Janeiro. The extent of occurrence (EOO) is 'the area contained within the shortest continuous imaginary boundary which can be drawn to encompass all the known, inferred or projected sites of present occurrence of a taxon, excluding cases of vagrancy' (IUCN 2001). We calculated the EOO of the Tropical Mockingbird using a buffer of $1,100 \mathrm{~m}$ from the coastline. In the state of Rio de Janeiro, the sandy portion of beaches do not exceed $100 \mathrm{~m}$, and the Tropical Mockingbird has been mainly recorded up to $1,000 \mathrm{~m}$ within the restinga vegetation (M.A.S. Alves pers. obs. 2010), hence a EOO of 1,100 m from the coastline. The historical EOO was based on the scientific literature produced between the $19^{\text {th }}$ century, when foreign naturalists registered their encounters with the Tropical Mockingbird during expeditions in Brazil, and the 1990's, when the first reports on the disappearance of the Tropical Mockingbird took place (a complete list of sources is available on request from the senior author). From that literature we inferred that the Tropical Mockingbird was a common and typical restinga species (Novaes 1950, Sick 2001), and that in Rio de Janeiro it originally occurred from Marambaia to the Barra do Itabapoana (easternmost historical limit, i.e., the State's boundary). Its historical range, therefore, was most likely continuous throughout the shoreline. The historical EOO was built using the buffer in the entire shoreline of the state of Rio de Janeiro, and the current EOO was the historical EOO minus the portions of restinga were the species was considered absent in our survey and the literature.

To estimate the historical and current regional population size in the state of Rio de Janeiro, we multiplied the mean population density derived from point counts by the historical and current EOO, respectively. This is the maximum regional population size, because it considers that the species occurs throughout its EOO. Nevertheless, because we know that a species does not necessarily occupy the entire region within its EOO (IUCN 2001), we estimated a minimum regional population size by multiplying the maximum regional population size by the probability of finding the species in a given area, i.e., the percent of the 20 areas within the species' original range in which we found the species to be present (following VALE et al. 2007). This is a minimum population size since the 
probability of finding the species is most likely underestimated because of detection problems. Hence, the species' regional population should be somewhere between the estimated maximum and minimum population sizes.

We used the current estimated EOO and population size to determine the species' conservation status in the state of Rio de Janeiro, applying the two-step process (sensu GärDENFORS et al. 2001, IUCN 2001, MiLler et al. 2007).

\section{RESULTS}

We did not find the Tropical Mockingbird at Praia do Sul, Ilha Grande (area 21, Table I), a relatively well preserved area according to RochA et al. (2007). This confirms that Marambaia is the westernmost limit of the species in the state of Rio de Janeiro and the southernmost limit of the species in South America, except for vagrants. Tropical Mockingbird populations were found at only four of the 20 areas that were surveyed by transect lines or casual expeditions within the known range of the species in the state of Rio de Janeiro (Table I, Figs. 1-3), translating into a probability of finding the species of only $20 \%$.

From our literature survey, the distribution of the Tropical Mockingbird in Rio de Janeiro originally ranged from Marambaia to the Barra do Itabapoana in the state's boundary (Fig. 1). Currently the species' range includes only four isolated areas that were originally part of its historical distribution (Figs. 2 and 3). The westernmost limit of the Tropical Mockingbird in the state of Rio de Janeiro is still Marambaia, but its easternmost limit has retreated to the Restinga de Jurubatiba, and gaps have appeared in the middle of its distribution (Fig. 3). The four currently known populations in the state of Rio de Janeiro occupy only about $250 \mathrm{~km}$ of shoreline, and are $211 \mathrm{~km}$ apart from the closest population, at Parque Estadual Paulo César Vinha, municipality of Guarapari, state of Espírito Santo (NARCISO 2012, L.C. de Araújo pers. comm. 2014).

In the four sites where point-count was performed, there was great variation in the number of individuals recorded, ranging from three to 38 individuals, which translates into a local population density between 10 and 121 individuals $\mathrm{km}^{-2}$ (Table II). The species' estimated EOO in the state of Rio de Janeiro

Table II. Tropical Mockingbird population size and density based on point counts, in the state of Rio de Janeiro, Brazil.

\begin{tabular}{lcc}
\hline Surveyed Area & Relative size (individuals) & Density (individuals $/ \mathrm{km}^{2}$ ) \\
\hline Jurubatiba & 38 & 121 \\
Marambaia & 8 & 25 \\
Massambaba * & 0 & 0 \\
Itapebussus & 3 & 10 \\
Average & 16.3 & 52.0 \\
\hline
\end{tabular}

*Although the species was recorded by the transect line method at this site, it was not observed during the survey by point counts. Therefore, its density was not taken into account for the average density computation.

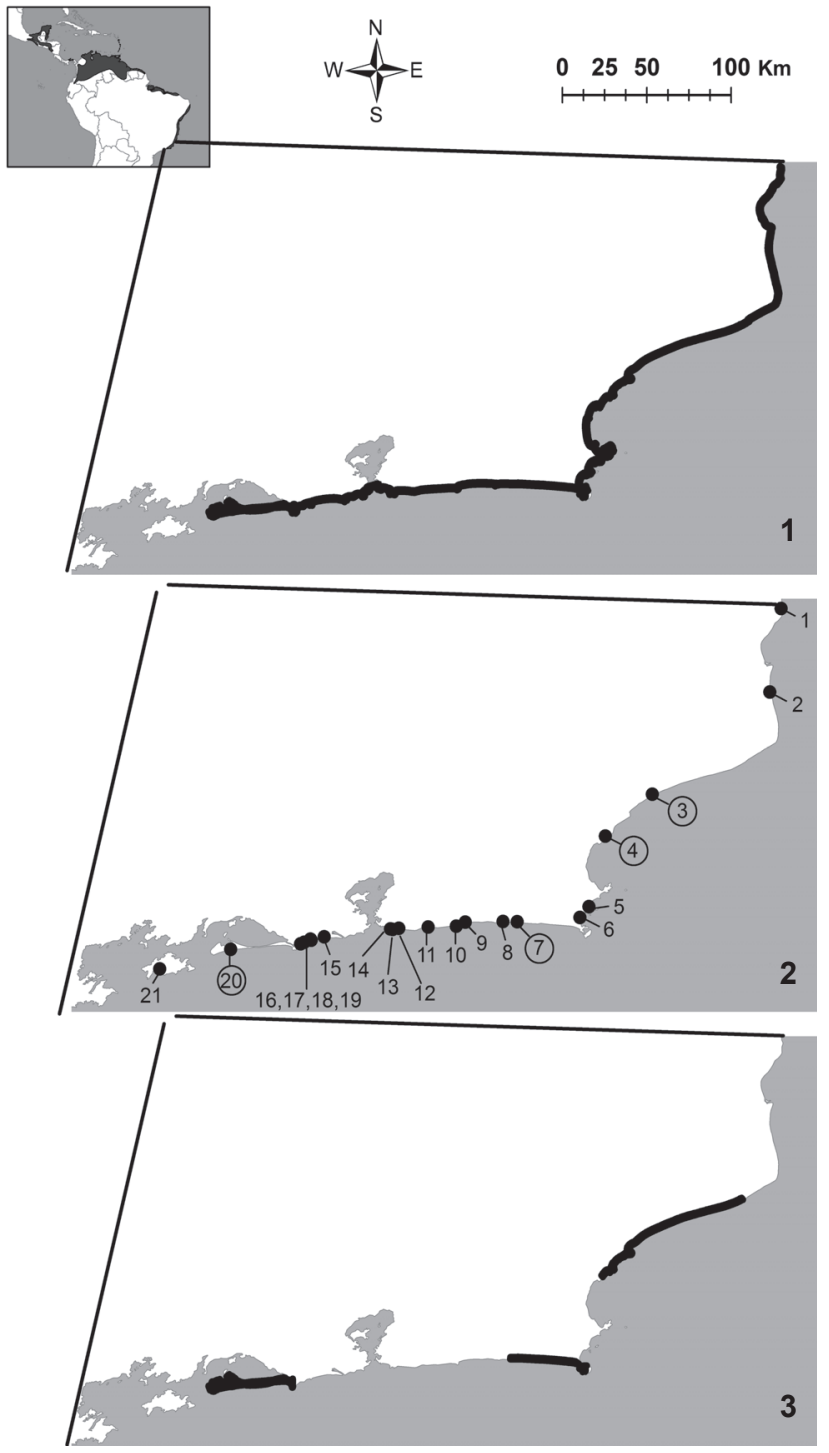

Figures 1-3. Distribution of the Tropical Mockingbird in the state of Rio de Janeiro, Brazil. The inset on the top left shows the global distribution of the species (from NatureServe.org). (1) Original area of occupancy (dark black line). (2) Areas surveyed in the study (numbers correspond to areas in Table I). Numbers in circles show the areas where the species was found. (3) Current area of occupancy (dark black line), depicting the four restinga remnants where the species is still found in the state of Rio de Janeiro.

was $256 \mathrm{~km}^{2}$, representing only 39\% of its original EOO of 653 $\mathrm{km}^{2}$. The current EOO of the Tropical Mockingbird in the state of Rio de Janeiro $\left(256 \mathrm{~km}^{2}\right)$, mean population density (52 individuals $\mathrm{km}^{2}$ ) and the probability of finding the species (20\%) translates into a population size ranging from 2,662 to 13,312 individuals in the state. Computing the original EOO $\left(653 \mathrm{~km}^{2}\right)$, 
we estimate an original population size of 33,904 individuals in the state of Rio de Janeiro, i.e., an estimated reduction of $61 \%$ to $92 \%$ in population size in the last 20 years.

After the two-step process (sensu GärdENFors et al. 2001, IUCN 2001, Miller et al. 2007), the Tropical Mockingbird was evaluated as regionally "Endangered", confirming previous non-quantitative assessments for the state of Rio de Janeiro (Alves et al. 2000). The species has an estimated EOO of $256 \mathrm{~km}^{2}$, meeting the 5,000-km² cut-off for the "Endangered" status (IUCN 2001), although being quite close to the 100-km cut-off for the "Critically Endagered" status.

\section{DISCUSSION}

Our study of the conservation status of the Tropical Mockingbird shows that the species is Endangered in the state of Rio de Janeiro, confirming previous qualitative assessments (Alves et al. 2000). Actually, the current Extent of Occurrence of the Tropical Mockingbird approaches the $100 \mathrm{~km}^{2}$ threshold for for the Critically Endangered species.

We estimated a population reduction between $30.5 \%$ and $46 \%$ in 10 years, meeting the threshold of $>30 \%$ reduction for the "Vulnerable" status, and an estimated population between 2,662 and 13,312 individuals, which is above the 10,000-individuals cut-off for the "Vulnerable" status. Because IUCN requires that species be listed at the highest threat category identified, we suggest the Tropical Mockingbird be listed as "Endangered" in Rio de Janeiro, 'facing a very high risk of extinction in the wild' (IUCN 2001). The proposed representation of its assignment is EN B1ab (I, III, IV, V), meaning that its EOO is less than $5,000 \mathrm{~km}^{2}$; our estimates indicate that the species exists in no more than five locations; and there is a continuing observed decline in its Extent of Occurrence, habitat size and quality, number of locations and number of mature individuals are in constant decline. We disregard a possible rescue effect from outside populations (GäRDENFors et al. 2001, Miller et al. 2007), because the Tropical Mockingbird is also listed as "Endangered" in the neighboring state of Espírito Santo (Simon et al. 2007). It was not found in the easternmost restingas of the state of Rio de Janeiro, and it apparently does not occur anymore in Neves, the westernmost restinga in Espírito Santo (M.A.S. Alves pers. obs. 2014).

This study surveyed the restingas of Rio de Janeiro very well. All nine major restinga sections identified by Araujo \& MACIEL (1998) were surveyed, including 18 of the 21 remnants identified by Rocha et al. (2007). We confirmed the local extinctions of the Tropical Mockingbird in Barra de Maricá, Niterói, and in the municipality of Rio de Janeiro (excluding the Restinga of Marambaia), previously mentioned in the literature (TeIXeIRA \& Nacinovic 1992, Argel-de-Oliveira \& Pacheco 1998, Araujo \& Maciel 1998, GonZaga et al. 2000), and recorded new local extinctions in the eastern portion of the state, above the Jurubatiba National Park (at Grussaí and Barra do Itabapoana remnants, in the extreme-west of Rio de Janeiro). From the results of the present study, obtained by a systematic survey (and some occasional visits), we also consider the species to be probably extinct in the municipality of Cabo Frio, as suggested by ArGEL-DE-OliveIRA \& PACHECO (1998). In 2007 two individuals were recorded at Praia Peró, Cabo Frio (M.B. Vecchi, pers.comm.), but were likely vagrants according to the source of the record itself and because our systematic survey at the site did not confirm the species' presence. The WikiAves citizen science website, however, has more recent records of the species at unspecified locations in Cabo Frio (http://www.wikiaves.com). Further scientific investigation should be carried out in order to determine whether these records are from vagrants or if the species is indeed returning to the region.

There are a number of possible explanations for the extinction of most populations of M. gilvus in Rio de Janeiro. One important factor might be the species' association with open shrubby restinga vegetation (SICK 2001), which is the first vegetation to disappear with occupation of the coastline (RocHA et al. 2007). In our study, we found that all remnants where the species was present had open shrubby restinga vegetation (although the inverse was not true), and that the species was absent from Grumari and Praia do Sul despite the good conservation status of these areas. These two restingas, however, are composed of dense and close vegetation. Another important factor in determining the species' presence might be the amount of available habitat. The Metropolitan Region of Rio de Janeiro and Niterói, where the species is no longer present, is extremely urbanized and degraded (except for Restinga of Marambaia, Rio de Janeiro) (FundaÇão Cide 2003). In addition, Maricá and Cabo Frio, which, together with the Metropolitan Region, correspond to the current gap in the middle of the distribution range of M. gilvus, have either been almost completely converted into pastures and agricultural fields, or have lost expressive vegetation cover (Fundação Cide 2003). Similarly, the boundary with the state of Espírito Santo, which once represented the species' westernmost limit in Rio de Janeiro, is currently predominantly taken by agriculture (FUNDAÇÃo CIDE 2003). At the same time, even relatively large and well preserved areas, such as Restinga of Grussaí (Rocha et al. 2007), have witnessed the local extinction of M. gilvus. This may result from more subtle pressures, such as the disruption of metapopulation dynamics. The severe fragmentation of the restingas of the state of Rio de Janeiro (RocHA et al. 2007) might prevent the migration of individuals from well preserved remnants, such as the Jurubatiba National Park. Populations from these areas could act as a source of individuals for sink populations (Pulliam 1988). Finally, another important factor in the extinction of M. gilvus populations is illegal capture, which is intense because of the remarkable singing abilities of this bird. According to local people, illegal capture does happen in the Jurubatiba National Park, Massambaba and Itapebussus, and there is also evidence that this also occurs in the restingas of 
Cabo Frio (J.F. Pacheco, pers. comm. 2008), Maricá, and the municipality of Rio de Janeiro (Argel-De-Oliveira \& Pacheco 1998).

Three of the four areas where the Tropical Mockingbird persists in the state of Rio de Janeiro are protected, to some degree, by natural reserves. Jurubatiba, which houses the largest population in our study, is within the Restinga de Jurubatiba National Park. The park is still relatively intact, despite insufficient law enforcement, land parcels that have not yet been expropriated, and open access to cars and people. Marambaia, which has a medium size mockingbird population, is not within a protected area, but is within a military area. The military prevent access to the major part of Marambaia, conserve noteworthy natural areas, and protect fauna against hunting. Therefore, despite not being within a protected area, the conservation status of the Marambaia is good (Rocha et al. 2007). Massambaba and Itapebussus shelter the smaller populations of the Tropical Mokingbird in the state of Rio de Janeiro. Massambaba was been recently incorporated into Costa do Sol State Park, and Itapebussus is within a municipally protected area. Both areas are immersed in a landscape that suffers from unplanned urbanization (including illegal occupation and excessive land parceling) and illegal captures of tropical mockingbirds.

The restinga ecosystem in general is protected by legislation at the national, state and municipal levels. At the national level, restingas are protected by the Forest Code (BrasIL 2012) and the Atlantic Forest Law (BRASIL 2006). The latter establishes, among other rules, that new facilities should be constructed preferentially in areas that have been already modified or degraded. In practice, however, restingas are under great urbanization pressure such as the construction of summer houses, resorts, ports, and the implementation of roads, pastures, and plantations at the shoreline (Araujo \& Lacerda 1987, Diegues 1999, Alves et al. 2000, Rocha et al. 2007, Mattos et al. 2009). In the state of Rio de Janeiro this is worsened by the fact that most restingas are not within protected areas (RocHA et al. 2007).

The Tropical Mockingbird has a very large global distribution, ranging from Mexico to southern Brazil, and therefore is considered of "Least Concern" by IUCN (2011). However, there are enough arguments to take its local disappearance seriously. First, in the southernmost portion of its distribution (excluding records of vagrants), the species is naturally restricted to the coast and is specialized in open restinga habitat. This southern form is described as M. gilvus antelius (HeLlmaYR 1934, Pinto 1944, Cody 2005, Restall et al. 2007), and possibly deserves to be considered as a separate species (CoDy 2005). If that is the case, this taxon will likely be threatened, given that it was listed as threatened in Rio de Janeiro and Espírito Santo, and is subjected to the very same human pressures in the remaining of its distribution. There is no red list of threatened species in the remaining ten states within its historical distribution, with the exception of the state of Pará in the Amazon, where the species is not listed (PARÁ 2007). Second, the geographical range of a species often begins to shrink at the border of its historical geographic distribution (CHANELL \& LOMOLINO 2000, Anjos et al. 2009). Populations at the border of the species' distribution are more vulnerable to extinction because they are often in marginal habitats, and seem to need greater areas to guarantee their continuity (Anjos et al. 2009). Furthermore, these populations usually have fewer available migrants from nearby populations that could rescue the population in case of a local extinction (ANjos et al. 2009). Thus, a small decrease in the range of a species is a good predictor of a much larger population reduction in the future (CHANell \& Lomolino 2000). After all, population extinctions precede species extinction (Ceballos \& Ehrlich 2002), and Mimus gilvus antelius has endured many local extinctions in the last decades. Although conservation tends to focus on extinctions at the species level rather than at the population level, local populations are the ones that play ecological roles in ecosystems, often providing services and goods to humankind (Ehrlich \& DaiLY 1993, Hughes et al. 1997, Сeballos \& Ehrlich 2002). For instance, the Tropical Mockingbird disperses restinga nurse plant species, suggesting that it can be a keystone species in the ecological succession of restinga bushes (Gomes et al. 2008, 2010) in areas like Jurubatiba, where it is one of the most abundant resident species (Alves et al. 2004).

"Typical of restingas" and "the restinga's most commonly spotted bird" are expressions that used to be employed in reference to the Tropical Mockingbird (Novaes 1950, SICK 2001). Ironically, the Tropical Mockingbird may currently be one of the most threatened restinga species, after the Restinga Antwren, Formicivora littoralis Gonzaga \& Pacheco, 1990, (MAtTos et al. 2009). We strongly recommend a taxonomic study of the southernmost populations of the Tropical Mockingbird in order to reveal its true taxonomic status. If it represents a different species, as suggested in the literature, then it is likely threatened with extinction. We also recommend enhanced environmental education and environmental regulations that aim to protect restinga areas (BRASIL 2006, 2012, Develey \& Pongiluppi 2010), in order to avoid further local extinctions.

\section{ACKNOWLEDGEMENTS}

We thank Edvandro Ribeiro for his extensive support with field work; Clinton Jenkins for English review; Instituto Biomas and UERJ for transportation; Idea Wild for equipment; INEA, SMAC, SEMAP and Base Aérea de Santa Cruz for research permits; CNPq for a MSc fellowship to MSZ (process 135861/2008 0 ) and a research grant to MASA (308792/2009-2); FAPERJ for a research grant to MASA (E-26/102837/2012); and PROBIO-II/ MCTI/JBRJ/MMA/GEF, PPBio/Rede BioM.A./MCTI/CAPES, and the Brazilian Research Network on Global Climate Change/ Rede Clima (Grant No. 01.0405.01) for support to MMV. 


\section{LITERATURE CITED}

Alves mas, Pacheco JF, Gonzaga laP, Cavalcanti RB, Raposo MA, Yamashita C, Maciel NC, Castanheira M (2000) Aves, p. 113124. In: Bergallo HG, Rocha CFD, Alves MAS, Van Sluys M (Eds) A fauna ameaçada de extinção do estado do Rio de Janeiro. Rio de Janeiro, EdUerj, 168p.

Alves Mas, Storni A, Almeida EM, Gomes VSM, Oliveira CHP, Marques RV, Vecchi MB (2004) A comunidade de aves na Restinga de Jurubatiba, p. 199-214. In: Rocha CFD, Esteves FA, Scarano FR (Eds) Pesquisas de longa duração na Restinga de Jurubatiba: Ecologia, História Natural e Conservação. São Carlos, RiMA, 376p.

Anjos L, Holt RD, Robinson S (2009) Position in the distributional range and sensitivity to forest fragmentation in birds: a case history from the Atlantic forest, Brazil. Bird Conservation International 20(4): 1-8. doi: 10.10.1017/s095927090999025

Araujo DSD (1992) Vegetation types of sandy coastal plains of Tropical Brazil: a first approximation, 337-348p. In: SEeLIGER U (Ed.) Coastal plant communities of Latin America. New York, Academic Press, XX+392p.

Araujo DSD, Lacerda LD (1987) A natureza das restingas. Ciência Hoje 6(33): 42-48.

Araujo DSD, Maciel NC (1998) Restingas fluminenses: biodiversidade e preservação. Boletim FBCN 25: 25-51.

Argel-De-Oliveira MM, Pacheco JF (1998) Um resumo da situação: Mimus saturninus e M. gilvus no litoral sudeste brasileiro. Boletim FBCN 25: 53-69.

Bornschein MR, Reinert BR, Pichorim R (1997) Notas sobre algumas aves novas ou poucas conhecidas do sul do Brasil. Ararajuba 5(1): 53-59.

BRASIL (2006) Lei Federal n 11.428 de 22 de dezembro de 2006. Diário Oficial da União 246: 1-4.

Brasil (2012) Lei Federal No 12.651 de 25 de maio de 2012. Diário Oficial da União 102: 1-8.

Ceballos G, Ehrlich PR (2002) Mammal population losses and the extinction crisis. Science 296(5569): 904-907. doi: 10.1126/science.1069349

Chanell R, Lomolino MV (2000) Trajectories to extinction: spatial dynamics of the contraction of geographical ranges. Journal of Biogeography 27(1): 169-179. doi: 10.1046/j.13652699.2000.00382.x

Cody M (2005) Family Mimidae (Mockingbirds and Thrashers), p. 448-495. In: Hoyo J Del, Elliot A, Christie D (Eds) Handbook of the birds of the world. Barcelona, Lynx Editions, vol. 10, 895p.

Develey PF, Pongiluppi T (2010) Impactos potenciais na avifauna decorrentes das alterações propostas para o Código Florestal Brasileiro. Biota Neotropica 10(4): 43-45. doi: 10.1590/ S1676-06032010000400005

Diegues AC (1999) Human populations and coastal wetlands: conservation and management in Brazil. Ocean \& Coastal Management 42(2-4): 187-210. doi: 10.1016/S0964-
5691(98)00053-2

Ehrlich PR, Daily GC (1993) Population extinction and saving biodiversity. AMBIO 22: 64-68.

FundAÇão CIDE (2003) Índice de Qualidade dos Municípios: Verde II. Rio de Janeiro, Fundação Centro de Informações e Dados do Rio de Janeiro, CD-ROM.

Gärdenfors U, Hilton-Taylor C, Mace GM, Rodríguez JP (2001) The application of IUCN Red List criteria at regional levels. Conservation Biology 15(5): 1206-1212. doi: 10.1111/ j.1523-1739.2001.00112.x

Ghizoni-Jr IR, Azevedo MAG (2010) Registro de algumas aves raras ou com distribuição pouco conhecida em Santa Catarina, sul do Brasil, e relatos de três novas espécies para o estado. Atualidades Ornitológicas 154: 33-46.

Gomes VSM, Correia MCR, Lima HA, Alves MAS (2008) Potential role of frugivorous birds (Passeriformes) on seed dispersal of six plant species of a restinga habitat, southeastern Brazil. Revista de Biología Tropical 56(1): 205-216.

Gomes VSM, Buckeridge MS, Silva CO, Scarano FR, Araujo DSD, Alves MAS (2010) Availability peak of caloric fruits coincides with energy-demanding seasons for resident and nonbreeding birds in restinga, an ecosystem related to the Atlantic forest, Brazil. Flora 205 (10): 647-655. doi: 10.1016/ j.flora.2010.04.014

Gonzaga LP, Castiglioni GDA, Reis HBR (2000) Avifauna das restingas do Sudeste: estado do conhecimento e potencial para futuros estudos, p. 151-163. In: Esteves FA, LACERDA LD (Eds) Ecologia de restingas e lagoas costeiras. Macaé, NUPEM/UFRJ, 446p.

Hellmayr CE (1934) Catalogue of the birds of the Americas. Chicago, Field Museum of Natural History, Zoology Series, vol. 13, Part 7, 531p.

Hughes JB, Daily GC, Ehrlich PR (1997) Population diversity: its extent and extinction. Science 278(5338): 689-692. doi: 10.1126/science.278.5338.689

Hutto RL, Pletschet SM, Hendricks PP (1986) A fixed-radius point count method for nonbreeding and breeding season use. The Auk 103: 593-602.

IUCN (2001) IUCN Red List Categories and Criteria. Gland, International Union for Conservation of Nature, v. 3.1, $\mathrm{IV}+32 \mathrm{p}$.

IUCN (2011) IUCN Red List of Threatened Species. International Union for Conservation of Nature, v. 2011.2. Available online at: http://www.iucnredlist.org [Accessed: 2 March 2012]

Machado ABM, Martins CS, Drummond GM (2005) Lista da fauna brasileira ameaçada de extinção: incluindo as listas das espécies quase ameaças e deficientes em dados. Belo Horizonte, Fundação Biodiversitas, 160p.

Mattos JCF, Vale MM, Vecchi MB, Alves MAS (2009) Abundance, distribution and conservation of the Restinga Antwren Formicivora littoralis. Bird Conservation International 19(4): 392-400. doi: 10.1017/S0959270909008697 
Meyer de Schauensee R (1970) A guide to the birds of South America. Philadelphia, Academy of Natural Sciences of Philadelphia, 498p.

Miller RM, Rodríguez JP, Fowler TA, Bambaradeniya C, Boles R, Eaton MA, Gärdenfors U, Keller V, Molur S, Walker S, Pollock C (2007) National threatened species listing based on the IUCN criteria and regional guidelines: current status and future perspectives. Conservation Biology 21(3): 684-696. doi: 10.1111/j.1523-1739.2007.00656.x

NARciso LC (2012) Parque Estadual Paulo César Vinha: preservando o nosso quintal. Cariacica, Espírito Santo, IEMA.

Novaes FC (1950) Sobre as aves de Sernambetiba, Distrito Federal, Brasil. Revista Brasileira de Biologia 10: 199-208.

PARÁ (2007) Resolução 054 de 2007. Available online at: http:/ /www.sectam.pa.gov.br/relacao_especies.htm. [Accessed: 25 November 2009]

Parker T, Stotz D, Fitzpatrick J (1996) Database A: zoogeography and ecological attributes of bird species breeding in the Neotropics, p. 250. In: Stoltz D, Fitzpatrick J, Parker III T, Moskovits D (Eds) Neotropical birds: ecology and conservation. Chicago, University of Chicago Press, $\mathrm{XX}+502 \mathrm{p}$.

PINTO O (1944) Catálogo das aves do Brasil: Parte 2. São Paulo, Secretaria de Agricultura, 700p.

Pulliam RH (1988) Sources, sinks, and population regulation. The American Naturalist 132(5): 652-661. doi: 10.1086/ 284880

Reis HBR, Gonzaga LP (2000) Análise geográfica das aves das restingas do Estado do Rio de Janeiro, p. 165-178. In: Esteves FA, LACERDA LD (Eds) Ecologia de restingas e lagoas costeiras. Macaé, NUPEM/UFRJ, 446p.

Restall R, Rodner C, Lentini M (2007) Birds of northern South America. New Haven, Yale University Press, vol. 2, $\mathrm{XX}+656 \mathrm{p}$.

Submitted: 4 March 2014

Received in revised form: 13 October 2014

Accepted: 16 January 2015

Editorial responsibility: Fernando de C. Passos
Ridgely RS, Tudor G (1989) The birds of South America. Austin, University of Texas Press, vol. 1, XVI+516p.

Rocha CFD, Bergallo HG, Van Sluys M, Alves mas, Jamel CE (2007) The remnants of restinga habitats in the Brazilian Atlantic Forest of Rio de Janeiro State, Brazil: habitat loss and risk of disappearance. Brazilian Journal of Biology 67(2): 263-273. doi: 10.1590/S1519-69842007000200011

Scherer-Neto P, Straube FC, Carrano E, Urben-Filho A (2011) Lista das aves do Paraná: edição comemorativa do "Centenário da Ornitologia do Paraná". Curitiba, Hori Consultoria Ambiental, 130p.

Sibley CG, Monroe BL (1990) Distribution and taxonomy of the birds of the world. New Haven, Yale University Press, XXIV+1111p.

Sick H (2001) Ornitologia Brasileira. Rio de Janeiro, Nova Fronteira, 912p.

Silveira LF, Uezu A (2011) Checklist das aves do Estado de São Paulo, Brasil. Biota Neotropica 11(Suppl. 1): 83-110. doi: 10.1590/S1676-06032011000500006

Simon JE, Antas PTZ, Pacheco JF, Efé MA, Ribon R, Raposo MA, Laps RR, Musso C, Passamani JA, Paccagnella SG (2007) As aves ameaçadas de extinção no estado do Espírito Santo, p. 47-63. In: Passamani M, Mendes SL (Eds) Espécies da fauna ameaçadas de extinção no Estado do Espírito Santo. Vitória, Instituto de Pesquisas da Mata Atlântica, 140p.

Teixeira D, Nacinovic JB (1992) Aves da Barra da Tijuca, p. 133145. In: Carvalho Hosken (Ed.) Parque da Gleba E, Rio de Janeiro: a entidade. Rio de Janeiro, Carvalho Hosken S.A., $152 \mathrm{p}$.

Vale MM, Bell JB, Alves MAS, Pimm SL (2007) Abundance, distribution and conservation of Rio Branco Antbird Cercomacra carbonaria and Hoary-throated Spinetail Synallaxis kollari. Bird Conservation International 17(3): 245-257. doi: 10.1017/S0959270907000743 